\title{
La visión plástica de la mujer en los dibujos de Federico García Lorca: aparente ingenuidad, drama surrealista y tragedia expresionista
}

\author{
José Luis PlAZA CHILLÓN* \\ Universidad de Granada \\ Thick, red and slipping. It is Adam's side, \\ This earth I rise from, and I in agony \\ (Sylvia Plath) \\ In memoriam Juan Argüelles
}

\begin{abstract}
RESUMEN. Federico García Lorca creará un complejo universo iconográfico femenino paralelo a sus personajes dramáticos y poéticos, con el que reivindicará el amor "carnal" como símil de su propio amor frustrado y reprimido. En sus dibujos de mujeres acudirá con asiduidad a líricas imágenes femeninas de raigambre andaluza que sufren su soledad de amor y obligada virginidad, otorgándoles un anhelo incorrecto y de acendrada melancolía; aunque en contraposición a estas "amables" mujeres, creará un mundo trágico y sangriento manifestado en unos pocos dibujos surrealistas. Sus heroínas se convertirán en figuras esencialmente reivindicativas que se proyectarán hacia una perspectiva eminentemente social.

Palabras clave: Federico García Lorca, Dibujos, Simbolismo, Surrealismo, Expresionismo, Homosexualidad, Erotismo, Castración, Muerte, Poesía, Dalí, Picabia, Masson, Nueva York.

ABSTRACT. Federico García Lorca will create a complex iconografic female universe parallel to his dramatic and poetic characteres, with wich we will use carnal love as simile of own love, repressed and frustrate. In his drawings of women, he regulary arrive at lyrical femenine images of Andalusian tradition, who suffer the lonliness of love and forced virginity, giving them a yearning melancholy wrong and umblemish; although in comparision to these kind of women, he will create a tragic and bloody world expressed in a few surrealist drawings. His heroines will become essential vindicate figures that will be projected towards an eminently social perspecive.

Key words: Federico García Lorca, Drawings, Simbolism, Surrealism, Expresionism, Homosexuality, Erotism, Castration, Dead, Poetry, Dalí, Picabia, Masson, New York.
\end{abstract}

\section{MUJERES: VÍCTIMAS Y ESTEREOTIPOS}

El mundo de lo femenino ocupa la atención de todo el corpus lorquiano, tanto poético como, sobre todo, dramático, sin entrar en particularismos biográficos lo suficientemente conocidos. Es un universo amplio y complejo, tal vez, no lo suficientemente estudiado, al menos con una me- todología adecuada, que lo aleje definitivamente de cualquier reminiscencia modernista. La versión plástica de la mujer lorquiana contiene imágenes portadoras de significados que nos ayudarán a la compresión global y el sentido último de este es-

\footnotetext{
* Grupo de Investigación: HUM-736 «Tradición y modernidad en la Cultura artística contemporánea»
} 
tudio. La conexión fundamental de dicha temática es la frustración amorosa de la mujer; un problema anunciado desde los albores literarios del poeta. De Mariana Pineda a $D^{\underline{a}}$ Rosita la soltera... si hablamos de teatro, y desde Libro de poemas a Suites, si nos referimos a poesía, García Lorca sintió una especial ternura por la condición íntima de unos personajes femeninos que como la "heroína" o la "solterona" entroncaban con la Granada decimonónica y de principios del siglo XX; influyendo en la niñez del poeta como la misma ciudad que le vio crecer y la región que le prestó su identidad. Como otros personajes del mismo sexo estas imágenes serán construidas de sucesos, tipos, anécdotas, nombres, apodos y gentes conocidas de los pueblos de la infancia de Federico. Quizá sea $D^{\underline{a}}$ Rosita la soltera... la denuncia más clara de la frustración amorosa en este universo femenino, aún más que en Yerma o en La casa de Bernarda Alba, generada por la opresión de unas estructuras sociales y formas de vida que coartaban la libertad en un tiempo en que el feminismo en España era ignorado, ridiculizado o duramente combatido ${ }^{1}$. La imagen de la castración bien puede reflejarse también en la intranquilidad de Lorca ante la sexualidad femenina dominante. Con sus obras sobre mujeres, Lorca está impartiendo la lección más amarga que ha aprendido desde la adolescencia, y espera crear en las mujeres la misma conciencia pre-política que su propia sexualidad reprimida le había aportado. Lorca se preocupará por lo sexual como ámbito de represión; sus obras nos hablan simultáneamente del varón y de la mujer heterosexuales y de la sexualidad homosexual, porque son por encima de todo un vehículo que da voz a la fuerza del deseo; "el placer y el deseo se mueven des-

\section{-}

${ }^{1}$ A. RODRIGO, «D $D^{\underline{a}}$ Rosita la soltera: teatro y realidad", en: A. SORIA OLMEDO, Lecciones sobre Federico García Lorca, (ed.) Granada, 1986, pp. 117-128. de el reino de la abstracción al dominio de la pasión". ${ }^{2}$

La preocupación lorquiana hacia personajes como " $\mathrm{D}^{\mathrm{a}}$ Rosita", que consideramos como la culminación del estereotipo femenino, había perdurado hasta la época del poeta y venía de una larga y execrable tradición ochocentista que convertía a la "solterona" en un "mal engendro" 3 , vertiéndose esta idea desde sus composiciones más tempranas; sólo tenemos que acudir a las obras de su "Teatro de juventud" o a los versos de Canciones o Libro de poemas para percibir la misma piedad, nada paternalista, que el poeta sintió hacia estos silenciados personajes cuya visión plástica también aparecería a principios de la década de los veinte. En las primeras versiones dibujísticas de "D” Rosita", "La zapatera" o "Mariana" son representadas como frágiles mujeres que sufren de amor en el anonimato de un olvido relegado a un apartado y solitario jardín donde lloran sus penas escondidas del miserable mundo masculino; personajes que pueblan un complejo universo de tradición romántica donde casi siempre se inscribe la palabra "Amor", acentuando todavía más la ausencia del ser amado o la propia dolencia del amor; y cuya iconografía es reiterada en dibujos como Muchacha granadina en un jardín (1924) y su homónimo dibujo de la Fundación Gregorio Prieto o la singular Monja profesa con corona de flores (1925), para culminar en las amputadas y surrealistas Venus (1927) o en el no menos sádico dibujo Martirio de Santa Rodegunda (1929), pasando por las andaluzas Dama con mantilla de madroños (1925), Soledad Montoya o Monja gitana (1930).

\footnotetext{
${ }^{2}$ D. Johnston, Federico García Lorca, Madrid, 2004, pp. 158-166.

${ }^{3}$ E. DE DIEGO, La mujer y la pintura del XIX español, Madrid, 1987, p. 118.
} 
Lorca, a través de estos personajes femeninos, reivindicará el auténtico amor "carnal" como símil de su propio amor frustrado y reprimido; para ello realizará una radical protesta contra una sociedad mediocre y burguesa dominada por unos valores morales decadentes; el poeta, como gran admirador de las corrientes simbolistas y modernistas, reinterpretará de manera muy particular la dualidad de los prototipos y estereotipos femeninos que habían caracterizado al arte y la literatura del "fin de siglo", donde predominaba como eje del mal, la "femme fatale", encarnada en la mujer carnal, amante, activa y fuertemente sexualizada a la vez que castradora en imágenes de Salomé, Judith o Eva; en contraposición de la mujer pura y desexualizada cuyo símbolo era la Virgen María, aunque de reminiscencia arquetípica ancestral en las sociedades primitivas patriarcales que combinaban armónicamente maternidad y sexualidad, y cuya dualidad se perdió con la llegada del cristianismo con todas sus connotaciones obsesivas y represoras que convirtieron al pecado en sinónimo de sexo. ${ }^{4}$ La imagen e idea de la mujer finisecular harán aparecer dos prototipos que se mostrarán bifurcadas y contrapuestas en la literatura y en el arte, haciéndose eco de esa contradicción hipócrita que dominó la sociedad en estos años convirtiendo a la mujer en dos: la mujer pecadora, perversa y artificial aunque bella y estéril, frente a la mujer sublimada como esposa y madre. La ciencia decimonónica había aportado argumentos que "probaban" la supuesta inferioridad mental de la mujer, "justificando" así su reclusión y tutela por parte del varón. Se daban interpretaciones negativas de la mujer defendidas por "ilustres" neurólogos como Gregorio Marañón; defendiéndose sólo el papel biológico de la mujer, de su estatus de madre y de su función social

${ }^{4}$ E. BORNAY, Las hijas de Lilith, Madrid, 1990, p. 43. dentro del matriarcado. Incluso el raro feminismo español se caracterizó por su conservadurismo y heterogeneidad; además, la iglesia católica, a través de los sermones y de la presión que ejercían los confesores, exhortaba a la abnegación y al sacrificio de las mujeres, pues la familia patriarcal parecía la base de la sociedad cristiana. ${ }^{5}$

El sexo se convertirá por tanto en tema tabú cuando menos en algo reprimido y relegado a lo más profundo del subconsciente, convirtiéndose en una práctica usada sólo con prostitutas por parte de los hombres, mientras sus "fieles" esposas tenían prohibido gozar del mismo. ${ }^{6}$ Es más, se consideraba que si alguna vez la mujer se liberaba del sexo, sólo podría tener resultados desastrosos porque de hecho el impulso sexual era en sí masculino: "El disfrute activo del sexo despertaba en la mujer un instinto criminal latente que era desastroso. Se volvía excesivamente erótica, su sentimiento maternal se debilitaba, se hacía disipada, astuta y audaz"; ${ }^{7}$ Además si no se casaba, era considerado aberrante, pero si lo hacía y tenía hijos, única y exclusivamente sería madre. Si practicaba deporte, podía convertirse en lesbiana o bisexual; por eso, la "nueva mujer" fue incapaz de inventar un renovado código de símbolos femeninos de poder o afirmarse en el lenguaje femenino existente, por lo que se apropió de los emblemas tradicionales de la autoridad asociados a lo masculino, hablándose de "masculinización de la mujer" y de su in-

\footnotetext{
${ }^{5}$ S. MANGINI, Las modernas de Madrid. Las grandes intelectuales españolas de la vanguardia, Madrid, 2001, p. 101. Véase, Catálogo-Exposición, Heroínas (A cargo de G. Solana) Madrid, 2011.

${ }^{6}$ L. LITVAK, Erotismo fin de siglo, Barcelona, 1979, p. 159.

${ }^{7}$ B. DIJKSTRA, Ídolos de perversidad. La imagen de la mujer en la cultura fin de siglo, Barcelona, 1994, pp. 157158.
} 
capacidad para la actividad racional. ${ }^{8}$ Como consecuencia la mujer se vio obligada y condicionada por el prototipo ideal al que según la moral establecida debía parecerse, a reprimir y someter su propio instinto sexual. Sobre todo ello indaga García Lorca en sus obras dramáticas, manifestando siempre su contrariedad y desapruebo de esta detestable tradición decimonónica, donde la protagonista es siempre la mujer; así lo reivindicará en $D^{a}$ Rosita la soltera... cuando manifiesta: " $\mathrm{D}^{\mathrm{a}}$ Rosita es la vida mansa por fuera y requemada por dentro de una doncella granadina, que poco a poco se va convirtiendo en esa cosa grotesca y conmovedora que es una solterona en España [...]. ¡Cuantas damas maduras españolas se verán reflejadas en $\mathrm{D}^{\underline{a}}$ Rosita como en un espejo! He querido que la más pura línea conduzca mi comedia desde el principio hasta el fin. ¿Comedia he dicho? Mejor sería decir drama de la cursilería española, de la mojigatería española, del ansia de gozar que las mujeres han de reprimir por fuerza en lo más hondo de su entraña enfebrecida". ${ }^{9}$

$\mathrm{D}^{\mathrm{a}}$ Rosita se convierte en una figura eminentemente social y reivindicativa, como también lo serán otros personajes paralelos en sus dramas; como Yerma, la novia de Bodas de sangre, Elenita, la niña que riega la albahaca, Aurelia y "sus sueños", la mariposa del "maleficio", la "señá" Rosita sin Don Cristóbal, Adela de La casa de Bernarda Alba, Belisa en Amor de Don Perlimplín... o incluso la heroína romántica granadina Mariana Pineda; todas ellas se proyectan

\footnotetext{
${ }^{8}$ M. LÓPEZ FERNÁNDEZ, «Emancipadas e intelectuales: El nacimiento de la mujer moderna en la pintura y la ilustración gráfica española de fin de siglo (1890-1914)», en: Actas del XIV Congreso Nacional de Historia del Arte. Correspondencia e integración de las artes, Málaga, 2004, pp. 325-343. T. II.

${ }^{9}$ F. GARCÍA LORCA, Obras Completas, Madrid, 1989, pp. 667-668. T. III (En adelante para referirnos a esta edición lo haremos con las siglas O.C.).
}

hacia una perspectiva eminentemente social. El conflicto que por ejemplo se plantea en Yerma, el de la esterilidad por un lado y el de la maternidad no-maternidad por otro, se dirige hacia una visión mítica y ancestral, transformado en los elementos que dominaban la sociedad española, representando la cara más tétrica, sombría y desgarrada del ser femenino en aquellos años. ${ }^{10}$ Federico había expresado públicamente el sentido mítico y trágico de la denominada "trilogía dramática" de la tierra española, entroncando directamente con los principios antagónicos de su universo dramático y poético: la libertad y la autoridad, integradas ambas en las citadas obras. ${ }^{11}$ Aunque no olvidamos que la verdadera esencia es su unión directa con el carácter mítico que tendrán las mismas y su conexión con la intemporal tragedia clásica. La lucha, la resistencia, la pasión o el destino crearán la esencia de la tragedia que sin ser un arma arrojadiza se convierte en la propia tragedia íntima del poeta; tal vez por eso propuso este modelo de creación dramática y poética de identificación con la esencia del drama interno femenino. ${ }^{12} \mathrm{Y}$ pese a todo, el modelo de la nueva mujer que reivindica Lorca era un hecho y una conquista, que más tarde o más temprano la sociedad tenía que asumir dentro de sus esquemas. ${ }^{13}$

El estricto condicionamiento social que aún pesaba con firmeza sobre gran parte de las mujeres en las primeras décadas del siglo XX fue denunciado claramente por Lorca en sus dramas, aunque se adelan-

\footnotetext{
10 R. DOMÉNECH, "Yerma: tres recursos estilísticos", $A B C, 24-X I I-1984$.

${ }^{11}$ G.F., «El teatro de Lorca. Un conflicto entre la autoridad y la libertad», Teatro, 30,1987.

12 C. FEAL, «Lorca: tragedia y mito», Ottawa hispanic studies, 4, 1989.

13 S. KIRKPATRICK, Mujeres, modernismo y vanguardia en España (1898-1931), Madrid, 2003, p. 220.
} 
tó tempranamente en algunos poemas, como el escrito en 1918 titulado "Elegía" y perteneciente al Libro de poemas, usando toda la imaginería de la literatura decadentista del "fin de siglo". ${ }^{14}$ Precisamente la iconografía artística derivada de esta poética recurrirá con frecuencia al mundo mitológico clásico, al Antiguo Testamento y a las "malvadas" mujeres de la antigüedad para configurar el doble mito de la mujer que Lorca lleva a su particular mundo poético y dibujístico; en dicho poema se refiere a ambas acepciones de esta manera: “...Como Ceres dieras tus espigas de oro / si el amor dormido de tu cuerpo tocara / y como la Virgen María pudieras / brotar de tus senos otra vía láctea [...] /Te vas por la niebla del otoño, virgen / como Inés, Cecilia, y la dulce Clara, / siendo una bacante que hubiera danzado / de pámpanos verdes y vid coronada...". ${ }^{15} \mathrm{El}$ poema está repleto de alusiones al doble mundo femenino y su visión finisecular, encontramos expresiones que se fijan explícitamente al universo de la "mujer fatal" como la referencia mitológica a Venus y sus bacantes, mujeres fuertemente sexualizadas y libres que experimentan la fuerza vital del erotismo o, por otro lado, la evocación de la mujer espiritual que aparece incluso como virgen y mártir, ahondando de esta manera en la otra cara de una imagen dual de la mujer. Planteamientos primigenios que se consolidaron como una constante fundamental en el acervo creador del granadino, tendiendo cada vez más claramente hacia una identificación consigo mismo, por eso es tan habitual que una de las claves de sus personajes dramáticos sea la frustración erótico-sentimental, converti-

-

14 A. CORREA RAMÓN, «Hacia una visión unitaria de la femineidad en la obra de Lorca: Un primer ejemplo en Libro de poemas», en: A. SORIA OLMEDO, M.J. SÁNCHEZ MONTES, J. VARO ZAFRA, (coord.) Federico García Lorca. Clásico / Moderno (1898-1998), Granada, 2000, p. 497.

15 O.C. T. I, pp. 39-41. da en elemento represor y castrante, aunque haya que especificar que esta doble visión se escinda con la palpitación de lo vivo; por eso la insistencia en ese afán de dar un áura a sus mujeres de rasgos primitivos, genéricos o mitológicos, mostrando esa vitalidad que destilan unos personajes completamente construidos con plena sexualidad, en la mayoría de los casos vilipendiada. ${ }^{16}$ Esa potencialidad de la energía vital femenina quedará anulada por los condicionamientos sociales e hipócritas de una sociedad que ignora la propia esencia femenina. En sus dibujos de mujeres acudirá con asiduidad a imágenes femeninas de raigambre andaluza: mujeres con mantilla, monjas, solteras que pasean su soledad por un jardín, gitanas de largos y expresivos cabellos, vírgenes que manifiestan su dolor en un trono de Semana Santa, muchachas tristes encerradas en la desolación de las cuatro paredes de una habitación..., presentadas con un especial lirismo sin aparente complejidad pero que psicológicamente sufren su soledad de amor y obligada virginidad, otorgándoles un anhelo incorrecto y de acendrada melancolía; dibujos como: La monja gitana (1930), Muchacha con miriñaque y sortija (1924), Muchacha en un paseo de cipreses (1930), Retrato de dama española sentada (1929), Dama española (1927), Mariana Pineda (1927), Maternidad (1924), o representaciones más innovadoras como Muchacha con gola sobre fondo negro (1924) o Musa de Berlin (1927). Todos estos dibujos muestran influencias que son fácilmente identificables en artistas próximos al granadino, como Dalí, o cercanos estéticamente como Picasso y Picabia, especialmente éste último, que con las tempranas series de damas españolas y su juego del desdoblamiento habían sido vistas precisamente cinco años

\footnotetext{
${ }^{16} \mathrm{~J}$. ALBERICH, «El erotismo femenino en el teatro de García Lorca», Papeles de Son Armadans, 39, 1965, pp. 34-36.
} 
antes de la exposición de Lorca en las galerías Dalmau (Barcelona, 1927), y que el andaluz pudo conocer a través de Dalí. Esto nos aporta una de las claves para comprender formalmente la cantidad de desdoblamientos de figuras que existen en los dibujos de Lorca, sin olvidarnos de las afinidades estéticas entre Dalí y Picabia en torno al humor cruel y masoquista, que harán evolucionar su arte. ${ }^{17}$

En contraposición a estas "amables" imágenes de mujeres, Lorca creará un mundo femenino, trágico y sangriento, manifestado, como veremos más adelante, en unos pocos dibujos. Tal y como refiere Federico en el poema "Elegía", y buscando la conjunción de dos fuerzas enfrentadas, el instinto sexual reprimido por un lado y el instinto maternal frustrado por otro, ambas se engloban en la potencialidad vital que de por sí tiene la mujer. Para el granadino no existe este conflicto dual sobre la femineidad que planteaban decadentes y simbolistas entre mujer pasional y espiritual (buenamala), ya que sobre ambas el "amor" (representado siempre de forma gráfica y explicativa en sus dibujos) no es nada banal, sino que se siente siempre vinculado a un sentido sagrado de la vida. Lorca, que se mostró crítico y rebelde contra la ortodoxia en todas sus facetas, pero sobre todo en la religiosa (católica), pretende y así lo hace, denunciar la hipocresía y el encorsetamiento de una rígida sociedad que impone a las mujeres un modo de vida inútil y sin sentido que él mismo intenta superar mediante la creación de sus personajes dramáticos, poéticos y plásticos. El poeta refundirá ambos prototipos con la fuerza primordial del "Amor", lo que conduce a una antigua y primigenia visión de la mujer como un todo, englobando la mujer "real" y la "arti-

-

\footnotetext{
${ }^{17}$ R. SANTOS TORROELLA, «Francis Picabia y Barcelona», en: Catálogo-Exposición. Francis Picabia (18791953), Madrid, 1985, pp. 49-63.
}

ficial" (pasional y espiritual) y concluyendo con una síntesis de contrarios integrados en una mujer que puede ser amante y esposa, madre y activa, espiritual y carnal, todo a un tiempo sin que supongan aspectos en conflicto. Lorca entiende bien a la mujer por el hecho de ser otro marginado de la sociedad de su tiempo (homosexual), de esta manera la enfoca, reconsiderándola y percatándose de su papel victimario, del puesto que la sociedad humana le asignó, acatando siempre las exigencias masculinas traducidas como una forma de conveniencia social. ${ }^{18}$ Resulta curioso que el homosexual sienta a la mujer, más como víctima que como rival; así nos apropiamos de las palabras de Gil-Albert, cuando dice que "sería interesante constatar hasta qué punto el aura ascendente del feminismo ha sido solapada, favorecida e ilustrada, en los anales modernos, por un vigoroso sentimiento homosexual, todo lo metafórico que se quiera" ${ }^{19}$ Erigirá a la mujer como protagonista absoluta de su obra, denunciando claramente la acción represora de las normas impuestas por una sociedad cruel e hipócrita que aniquilará cualquier atisbo de libertad.

\section{GENITALIDAD FEMENINA}

La historiografía actual ha empezado a sospechar que la cultura de la segunda mitad del siglo XIX no es tan sólo la que emerge con los impresionistas como guías, sino que hay otra parte (nocturna, desdoblada y neurótica) que se identifica con el simbolismo y que se prolongará hasta las vanguardias. Será el fin de siglo el que recupere una serie de mitologías (clásicas, bíblicas y medievales a través de los prerra-

\footnotetext{
${ }^{18}$ M. M. RIVERA GARRETA, La diferencia sexual en la historia, Valencia, 2005, pp. 129-142.

${ }^{19}$ J. GIL-ALBERT, Heraclés. Sobre una manera de ser, Valencia, 2001, p. 84.
} 
faelitas y los "Rose-Croix") dejando una profunda huella difícil de borrar. En torno a este grupo se movieron artistas como Moreau, Puvis de Chavannes, Knopff o Felicien Rops creando un universo de mitos e imágenes que iban del misticismo a la perversidad, de la religiosidad al satanismo, pasando por el dogma, el misterio y la iniciación. Los temas eran tan variados como extravagantes: el sueño, la memoria, los lugares que evocaban Bizancio o Egipto, la Sodoma maldita, Satán; pero también San Antonio y sus "tentaciones", San Jorge, la sirena, Salomé, el Bautista, San Sebastián, el andrógino..., temáticas que Lorca recuperará no sólo en su obra literaria ("Poemas en prosa"), sino también en sus creaciones plásticas, aunque transformando parcialmente el sentido de las mismas; todos estos seres ambivalentes y las "mujeres fatales" se convertirán en protagonistas esenciales y transgresoras de una época especialmente misógina. ${ }^{20}$

En esta larga tradición que recorre todo el siglo XIX y llega hasta el XX, tiene su centro de acción durante el "fin de siècle", donde la mujer es representada como "fatal" y culpable de todos los males que aquejan al hombre, pero sobre todo $\mathrm{y}$ dicho en términos freudianos, el temor a que se ve sometido el hombre a ser castrado por la mujer; dentro de este mundo dominado por los "estetas sexuales" (Wilde, Sâr Peladan o Beardsley), se generará un universo iconográfico tan rico como complejo, erigiendo en protagonistas a las "malas" de la historia y la mitología: Salomé, Cleopatra, Helena de Troya, Dalila, Betsabé, Andrómeda, Leda, etc; simbolizando ora la seducción, la animalidad, ora la castración,

${ }^{20} \mathrm{M}$. FAGIOLO, «Los grandes iniciados. El revival Rose-Croix en el período simbolista», en: G. C. et ALT. ARGAN, El pasado en el presente. El revival en las artes plásticas, la arquitectura, el cine y el teatro, Barcelona, 1977, pp. 95-127. el vampirismo. La imagen icónica de "Mona Lisa" llegó a encarnar incluso el estereotipo decimonónico de la mujer seductora aunque mortal, identificándose como la encarnación de la "Medusa" castradora masculina además de simbolizar la androginia; así fue interpretada años después por Duchamp cuando le añade bigotes al rostro de $L a$ Gioconda en su esencial obra L.H.O.O.Q. ${ }^{21}$

La misoginia se mantendrá manipuladamente en el masculino mundo del surrealismo, dentro de las numerosísimas "trampas" urdidas sobre la construcción del ideario femenino (recordemos a Nadja, protagonista de la novela homónima de Bretón, presentada como intuitiva, telepática e irracional). Quizá porque fueron incapaces de enfrentarse a las mujeres, temiéndolas y tratando de desactivarlas a través de unos particulares estereotipos que, bajo una apariencia liberadora, no hacían sino establecer renovados lazos de esclavitud; por eso, los temas "fin de siècle" de la "mujer-niña", la "mujer-esfinge", la "mujernaturaleza" o "histérica" se convierten en las recién estrenadas categorías de lo femenino, aquellas que subrayan la gran aportación de las mujeres al mundo: lo irracional y el inconsciente, básicos para la conformación de la estética surrealista; como ha señalado certeramente Estrella de Diego, “...los hombres surrealistas decían estar hablando de la libertad de las mujeres, pero hablaban de sus propios deseos; creían estar hablando de sus deseos y hablaban de sus mie$\operatorname{dos}^{\prime \prime}{ }^{22}$

El rechazo al sexo femenino se dibuja sin ninguna duda en el poema en prosa de Lorca, "Amantes asesinados por una per-

\footnotetext{
${ }^{21}$ J. A. RAMÍREZ, Duchamp el amor y la muerte, incluso, Madrid, 1993, pp. 46-51.

${ }^{22}$ E. DE DIEGO, Querida Gala. Las vidas ocultas de Gala Dalí, Madrid, 2003, p. 87.
} 
diz" y el tema recurrente de la mujer como culpable esencial de la castración. La mujer se oculta tras la imagen simbólica de la perdiz, cuya asociación es la propia identificación del ave (perdiz) con la luna, paralela a la que se traza entre la mujer y el astro en otros poemas y dibujos. Evocamos, en este sentido, la dulzura y el lirismo del dibujo Teorema de la mujer que se come a la luna, La Habana (1930), donde metafóricamente se produce la unión simbólica entre lo lunar -femenino- y el amor; contrastando con trágicas visiones de otras representaciones femeninas, como Agua sexual, que sirvió para ilustrar el poema homónimo de Pablo Neruda (junto a otros dibujos), Paloma por dentro, o sea, la mano de vidrio (1934), donde las amputaciones de miembros, los abultados labios, las alusiones seminales o el sangriento sexo de la mujer, desborda y domina todo el dibujo de forma amenazante, pero sin renunciar nunca al "amor", palabra repetida por toda la lámina; o el todavía más desconcertante Epitalamio (1928), que fue enviado, junto a otros dos dibujos más, al editor Juan Guerrero Ruiz en una carta con motivo de la publicación del poema en prosa "La degollación del Bautista", en la que especifica el deber de cuidarlos al reproducirlos para que las "líneas no pierdan emoción, que es lo único que tienen", y que representa una vulva de grandes dimensiones con abundante vello, puramente sexual, aunque de aséptico erotismo; la imagen se acompaña de una serie de líneas y puntos que quiebran el dibujo por un lado, mientras en el centro se representan otras más sinuosas y unidas, que quizá aludan al falo antes de la consumación. Es un dibujo único en su género, de evocaciones psicoanalíticas que rechazan el acto heterosexual o, tal vez, el miedo a su propia homosexualidad; una suerte de "vagina dentata" que iconográficamente comenzaría a desarrollarse en la literatura y el arte producidos por la psicopatología sexual francesa de finales del XIX, transformándose en el surrealismo en un "monstruo híbrido". Contemporáneo al anterior es también Fecundación del niño azucena, regalado a Dalí en 1927 y en el que vuelven a repetirse los mismos elementos formales e iconográficos, y cuya contemplación evoca el contenido de una temprana carta enviada a su amigo Adriano del Valle en 1918, que anuncia, de alguna manera las connotaciones sexuales y complejos edípicos que poblará más adelante su obra; dice así parte de la misiva: "Soy un pobre muchacho apasionado y silencioso, que casi como el maravilloso Verlaine, tiene dentro una azucena imposible de regar y presento a los ojos bobos de los que me miran una rosa muy encarnada con el matiz sexual de peonía abrileña, que no es la verdad de mi corazón"; ${ }^{23}$ la verdad del corazón del poeta poco tenía que ver con la sexualidad simbolizada tradicionalmente por las rosas encarnadas y la presencia de la azucena de Verlaine, tal vez, sugiere que empieza a asumir su homosexualidad. ${ }^{24}$ La simbología sexual se manifiesta un tanto ambigua en el dibujo, aunque el título sea tan evidente como su propia composición metamórfica, donde los elementos fisiológicos se mezclan con los telúricos, transformándose en un extraño ser que recuerda bastante a algunas composiciones del más metafórico de los pintores surrealistas, Max Ernst, con una iconografía tan compleja como transformista. ${ }^{25}$

El sentido castrador de la mujer del poema "Amantes asesinados por una perdiz" puede observarse codificado en el sugerente "poema-dibujo-caligrama" neoyorquino Puta y luna, donde de una manera trágico-burlesca, el artista hace confluir

${ }^{23}$ O.C. T. III., p. 691.

${ }^{24}$ I. GIBSON, Lorca-Dalí. El amor que no pudo ser, Barcelona, 2000, pp. 41-42.

${ }^{25}$ A. Muthesius, B. RiemsChNeIDER (Ed.), El erotismo en el arte del siglo XX, Colonia, 1993, pp. 51-64. 
toda una serie de líneas a modo de arabesco en una luna negra (mujer), declinando la palabra "puta" (pota, pita, peta, pata) y ensalzando el astro nocturno, presidido por un extraño y "fabuloso animal", que se convertirá en el protagonista indiscutible de los dibujos realizados en Nueva York (192930); en esencia, dicho dibujo, ilustra por sí mismo el sentido metafórico de gran parte de sus dibujos y de su obra literaria: "puta" como elemento sexual, y "luna" como sinónimo de muerte (Eros y Tánatos). Lorca abunda todavía más cuando compara a la perdiz con una "paloma cruelísima que tiene el corazón de elefante", como un ave simbólica e imagen de Venus, que despojándose del falso e idealizado candor romántico con que le ha adornado, deja ver su transformación real; el de un "ave-mujer" rendida al gigantesco y elemental impulso erótico de la cópula y la procreación; precisamente ese carácter lujurioso de la paloma había sido puesto de relieve por Lorca en la conferencia "La imagen poética de Luis de Góngora”, cuando decía, “... o llama a la paloma, quitándose con razón su adjetivo de cándida: Ave lasciva de Cynia Diosa",26 también Dalí sugería lo mismo cuando, desmitificando al animal, lo tacha de cruel y antipático, alejándose de posteriores significados pacifistas. ${ }^{27}$ Idéntica interpretación encontramos en "Amantes asesinados...", cuando escribe "....ंSerá posible que el pico de esa paloma cruelísima que tiene corazón de elefante salga la palidez lunar de aquel trasatlántico que se aleja... [...]. Sólo sé deciros que los niños que pasaban por la orilla del bosque vieron una perdiz que echaba un hilito de sangre por el pi$\mathrm{co}^{\prime \prime} .{ }^{28}$ Estamos, por tanto, ante una imagen

-

${ }^{26}$ O.C. T. III, p. 241.

${ }^{27}$ R. SANTOS TORROELLA, (ed.) «Salvador Dalí escribe a Federico García Lorca (1925-1936)», Poesía. Revista ilustrada de información poética, 27-28, 1987, p. 83.

${ }^{28}$ O.C. T. III, pp. 161-162. zoomorfa de la mujer "fuerte" que los estetas finiseculares odiaron y adoraron de forma diferente. Lorca la convierte, sin embargo, en la opción fecunda del amor, que sólo persigue la animalidad en el hombre (Sansón y Dalila), adscribiéndose en consecuencia a la proscripción del "amor fou" y tanático del deseo homosexual; traspasa, por tanto, el carácter puramente biológico de la perdiz y su impulso a la procreación.

\section{SEXUALIDAD MUTILADA}

Dentro del contexto estético de los dibujos que "iluminan" los "Poemas en prosa", existe uno que se convierte por sí mismo en el eje vertebrador del corpus dibujístico lorquiano, rompiendo radicalmente con el apacible, aunque desolado, mundo femenino planteado en sus primeros dibujos; se trata de Venus (1927-1928); este dibujo se aleja radicalmente de la estética plácida y melancólica que desprenden sus "Rositas", "Marianas" y demás muchachas tristes; la figura femenina se rompe en mil pedazos, no sólo formal, sino y sobre todo, poéticamente. En su fingida desnudez académica, evocadora de la diosa grecolatina, la fragmentación de los miembros hacen de esta figura una suerte de "escultura pintada" de reminiscencias helénicas; aunque su innovadora visión venga acompañada de un contrapunto onírico claramente inspirado en los desangelados maniquíes metafísicos de los admirados Giorgio De Chirico y Alberto Savinio; que habían sido interpretados en España por pintores cercanos al granadino como Gregorio Prieto, Maruja Mallo o Dalí, pero especialmente Juan Antonio Morales, colaborador con Lorca en proyectos escenográficos como Yerma ${ }^{29} \mathrm{O}$ el pintor canario Juan Ismael cuya

${ }^{29}$ L. ARIAS SERRANO, «El eco de Ortega en la vanguardia española: Juan Antonio Morales y los poetas del 27», Goya, 223-224, 1991, y J. L. PlazA CHILlóN, Escenografía y artes plásticas: el teatro de Federico García 
atracción por la poética metafísica italiana lo acerca a este inquietante y silente mundo femenino. ${ }^{30}$ Esta "Venus" lorquiana acentúa su complejidad al introducir elementos explícitamente sexuales de evidencia sadomasoquista: pechos seccionados, vulva abierta y herida con abundante vello púbico, y algún signo específicamente daliniano, como la afilada muleta que se hinca hiriendo el muslo, atributo iconográfico utilizado en diversas obras del catalán, como Cenicitas (anteriormente Nacimiento de Venus y Los esfuerzos estériles) y La miel es más dulce que la sangre (originalmente llamada Bosque de aparatos). Estas eran las palabras que el granadino enviaba a Sebastián Gasch en julio de 1927, donde también participaba Dalí escribiendo lo siguiente: “...y a mes preparo una llarga carta parlante del meu 'bosc d'aparatus' y del naixement de Venus que estan ja començats...", ${ }^{31}$ aludiendo a los títulos de las obras antes mencionadas.

Era normal en García Lorca acudir a la mitología clásica para buscar inspiración en sus creaciones poéticas, recordemos el Romancero gitano y los "poemas en prosa", o el concepto de tragedia que desprenden sus dramas rurales. Con Venus transgredirá la propia esencia del mito de la diosa grecolatina para convertirla en referencia directa de sus propias obsesiones, sin excluir el posible interés erótico, sádico y tanático, produciendo un efecto estético que hasta ahora no se había producido en su obra plástica; este especial erotismo podríamos definirlo como "lo hermoso más lo transgresor". ${ }^{32}$ Pero como en gran parte de su obra literaria, el poeta buscará con esta

Lorca y su puesta en escena (1920-1935), Granada, 1998, pp. 381-385.

${ }^{30}$ L. GARCÍA DE CARPI, La pintura surrealista española (1924-1936), Madrid, 1986.

31 O.C. T. III, p. 952.

32 A. JULIUS, Transgresiones. El arte como provocación, Barcelona, 2002, p. 65. especial expresión plástica, la verdad que le dicta su corazón, y como un Edipo moderno tendrá que enfrentarse al enigma de sus propias preguntas y respuestas, de ahí dependerá la negación o afirmación de su identidad; quizá por eso recurre tan a menudo al mundo de la mitología tratando de dar salida a su propio conflicto interior en el que dirime su homosexualidad y sus postergadas consecuencias castradoras. Pero dicha fijación por la mitología no era nueva, ya que su apasionado gusto por los poetas simbolistas y modernistas lo llevarían una y otra vez a este parnasiano universo. Desde sus más tempranas obras mostrará un especial interés, acentuando incluso el "horror" que le producen ciertas figuras femeninas como símbolos castradores y que enmascara buscando una resolución de ese "miedo" mediante una alegoría mítica, transformada aquí en "Venus". Fijémonos en un significativo fragmento de una prosa de juventud donde alude al poder maléfico de las "náyades" que compara a las "sirenas" homéricas con su canto de seducción y muerte: “...Me horrorizo... Abro los ojos. Lo que yo me figuraba: culebras con unos brazos de mujer. A mi alrededor nadan muchas [...]. La náyade que me aprisionó en sus brazos traidores juguetea conmigo [...]. Otra náyade la acompaña con una lira hecha riscos con serpientes de cuerdas. Me rodean una nube de mujeres; todas me pellizcan y cantan bajo. Sus voces son dulcísimas [...]. Las náyades me muerden furiosas porque he besado a una de ellas." ${ }^{33}$ Las referencias clásicas son tan evidentes como su propio significado, donde el terror juvenil a lo femenino, como símbolo de la muerte, se transforma en sexualidad castrada. La raíz mitológica que desprende su obra afirma, por otra parte, una absoluta correspondencia entre mujer y naturaleza

${ }^{33}$ F. García Lorca, Prosa inédita de juventud, Madrid, 1994, pp. 186-187. 
teniendo como sentido la defensa de lo primigenio, de lo arquetípico, de lo ancestral como principios cosmogónicos en los que la mujer se sabe inscrita. ${ }^{34}$

García Lorca con el dibujo de Venus se aleja de la poética de interpretaciones cubistas cantadas en la "Oda a Salvador Dalí". Dalí comienza a dar un cambio radical que empieza a concretarse en su participación con un dibujo en la malagueña revista Litoral, en el número triple homenaje a Luis de Góngora, y cuyo dibujo suponía un acercamiento a los análisis freudianos que tanto le cautivaban, dándole un aire críptico tan similar a la pretendida "oscuridad" gongorina, aunque haya indicios para considerarlo también como un dibujo "automático" que no responda a una intencionalidad previa, sometiéndose así a uno de los postulados del surrealismo bretoniano, insistiendo en sus obsesiones de autoerotismo y fragmentada sexualidad. ${ }^{35}$ Pero serán La miel es más dulce que la sangre y Cenicitas las obras que contienen los elementos definidores del dibujo lorquiano: sexos femeninos, senos, enjambres, salpicaduras de puntos, partículas y toda suerte de hormigueantes pululaciones, manchas viscosas, miembros amputados, degollaciones, fragmentaciones venosas, etc., con el contrapunto de unos cuerpos femeninos a un tiempo incitantes y monstruosos, bellos y repulsivos, evocadores y castrantes. De esta manera idea Lorca su dibujo, no exento de tintes masoquistas a la sombra de El nacimiento de Venus (Cenicitas); aunque no se trataría exactamente de la diosa grecolatina como recreación mítica y clásica de la mis-

\footnotetext{
${ }^{34}$ G. VALLEJO FORÉS, «Sublimación mitológica del amor en clave lorquiana», en: A. SORIA OLMEDO, y OTROS (ed.), Federico García Lorca. Clásico..., pp. 605-606; y M. ELIADE, Mito y realidad. Barcelona, 1991, pp. 151153.

35 R. DESCHARNES, Dali, la obra y el hombre, Barcelona / Lausana, 1984, p. 66.
}

ma, sino la de las resonancias anímicas que aquel nacimiento provocaba en Dalí y Lorca en esos días de confusión y represión erótica, cuyas intrínsecas dudas eran evidentemente compartidas. Dalí se inspiró para Cenicitas en una reinterpretación del Nacimiento de Venus de Boticcelli, llamando especialmente la atención sobre el mutilado y yacente cuerpo femenino que se halla un tanto oculto en el ángulo inferior de la composición, convertido en el particular homenaje daliniano a la obra del pintor florentino, complementado por los demás cuerpos cercenados y rotos, que vuelven a aparecer en La miel es más dulce..., donde el radical contraste del sugestivo canon de belleza clásica del cuerpo se enfrenta con la desmesurada carnosidad del deforme desnudo que flota entre las cabezas de Lorca y Dalí, dando la clave intencionada de lo que el granadino quiso plasmar en la obra del catalán. ${ }^{36}$

La fascinación que muchos artistas y teóricos de la vanguardia sintieron por la láminas de anatomía que mostraban las interioridades de los cuerpos ya fuera total o parcialmente (músculos, tendones, arterias, venas, huesos, etc.), fue bastante importante, aunque al fin y al cabo sólo era un recordatorio de los estudios artísticos tradicionales; pintores como Dalí, Masson, Giacometti o Matta presentan temáticas similares donde el descuartizamiento de miembros es habitual, y el amor se alía con la sangre, o donde el lecho del placer parece emular a una carnicería. ${ }^{37}$ Fue una constante en la vanguardia, sobre todo dentro de los parámetros del surrealismo, el tema obsesivo mitológico del héroe o dios (diosa,

\footnotetext{
${ }^{36}$ R. SANTOS TORROELLA, «El nacimiento de Venus y su dibujo en Litoral», en: J. GARCÍA GALLEGO, (ed.), Surrealismo. El ojo soluble, Málaga, Litoral, 1987, p. 6467.

${ }^{37}$ J. R. RAMíReZ, Dalí: lo crudo y lo podrido, Madrid, 2002, pp. 45-49.
} 
en este caso) descuartizado, mutilado y torturado; se trata de una temática ligada al movimiento surrealista francés y se manifiesta como la representación extrema del cuerpo en obras como, las Anatomíes de Picasso, las Poupeès de Bellmer o las Distorsiones de Kertész, donde los cuerpos aparecen insistentemente asociados a la violencia y el sacrificio o la desmembración ${ }^{38}$. Una temática que tendrá consecuencias fructíferas en la posmodernidad de la mano de pintoras e ilustradoras como la portuguesa Paula Rego, que desde su condición femenina (y feminista), abundará en una iconografía de la mujer traumática y perturbadora. ${ }^{39}$

Uno de los pintores coincidente en las soluciones gráficas y pictóricas con García Lorca será el francés André Masson; sobre todo, cuando el poeta granadino describe la técnica con que elabora sus dibujos en ese "abandonar la mano" como recurso de la espontaneidad o el reclamo a la inmediatez, interpretado como un metafórico acercamiento a los dictados del "automatismo". La conexión lorquiana más ligada a la tendencia de la "pintura-poética", induce a una cierta unión con el surrealismo en lo que tiene de exaltación del lirismo, la subjetividad y la imaginación. Sea como fuere Lorca llegará a afirmaciones que lo ligan en algunos aspectos con la poética gala, así en su imprescindible "Sketch de la pintura moderna," dice: "La pintura, después del objetivismo agudo a que llegó en 1920, llega hoy sapientísima y vieja a un campo lírico donde necesariamente, siguiendo un proceso biológico, que salir desnuda de su anti-

\footnotetext{
38 J. A. AliagA, Ese cataclismo que era mi cuerpo. El cuerpo y su representación extrema en Francia, 1930-1960, San Sebastián, 1994-1995, pp. 65-117.

${ }^{39}$ G. GREER, La carrera de obstáculos. Vida y obra de las pintoras antes de 1950, Madrid, 2006; y CATÁLOGOExPOsICIÓN, Paula Rego (A cargo de M. Livingstone), Madrid, 2007.
}

gua piel, pintura niña, hermana de las estilizaciones de la época cavernaria y prima hermana del exquisito arte de los pueblos salvajes". ${ }^{40}$ Estas apreciaciones cercanas a las ideas estéticas de su amigo Sebastián Gasch, suponen un acendrado valor del "primitivismo", alineándose con lo arquetípico y el "topos" mitológico. Este es el momento de los "poemas en prosa" con su carga sadomasoquista ${ }^{41}$, o la hora del suplicio y martirio de "San Sebastián"..., pero también responden a esta poética sus Venus, como la regalada a Gasch, o la que aparece en el ejemplar del Romancero gitano dedicado al pintor Néstor en la página 104 frente al "Romance de la guardia civil", titulado también Venus (1928), cuya figura aparece desmembrada y mutilada sexualmente, o la desoladora Venus (1934) del libro de Neruda "Paloma por dentro..." en la portadilla del poema "Agua sexual"; además del Martirio de Santa Rodegunda (1929) y casi la totalidad de los dibujos creados en Nueva York.

El grandioso erotismo de Masson tiene profundas afinidades con el de $\mathrm{Wi}$ lliam Blake, y, desde luego, con el lorquiano. El artista galo sostuvo una intensa relación con España tras su estancia entre los años 1934 y 1936, influyendo decisivamente en algunos artistas. Su obra presenta puntos de conexión con los temas que obse-

\footnotetext{
${ }^{40}$ O.C. T. III, p. 278.

${ }^{41}$ A los seis poemas que forman el "corpus" ineludible de los "Poemas en posa" ("Santa Lucía y San Lázaro", "Nadadora sumergida", "Suicidio en Alejandría", "Amantes asesinados por una perdiz", "Degollación de los inocentes" y "Degollación del Bautista"); se han sumado últimamente: "La muerte de la madre de Charlot", el esbozo de "Coeur azul-corazón bleau" y también habría que defender la pertenencia al mismo de "La gallina. Cuento para niños tontos"; J. HuÉLAMO KOSMA, «Los poemas en prosa: Lorca ante la encrucijada», en: A. SORIA OLMEDO, Ma J. SÁNCHEZ MONTES y J. VARO ZAFRA (coord.). Federico García Lorca. Clásico / Moderno (1898-1998), Granada, 2000, p. 110.
} 
sionaban a Goya, sin olvidar los homenajes a Velázquez, Góngora o el contemporáneo Picasso. ${ }^{42}$ Las escenas de sexo y violencia y la preocupación por el destino del hombre son un elemento constante en su obra, afines a las ideas de Nietzsche, que también planean sobre la poética lorquiana del dolor y la violencia. ${ }^{43}$ Masson en su admiración por Sade consigue expresar mejor que nadie los profundos y desgarradores valores religiosos y rituales del erotismo. ${ }^{44} \mathrm{La}$ obra de Masson se introduce en la órbita de lo antropológico y en las relaciones entre mito y ritual, por eso el héroe-dios perece de forma violenta ya sea a consecuencia de una profunda herida, de una mutilación o de un desmembramiento. Unido todo a un sentido del erotismo, animalidad y muerte que representan una profunda ruptura de un sexo sonriente y amable, sino que aparece como violento y destructivo, un erotismo sombrío y ligado íntimamente a la idea de la muerte; este sentido de la obra "massoniana" puede ser comparable a las representaciones gráficas que surgen como consecuencia de la escritura de los "poemas en prosa" o viceversa, ya que las obras de Lorca son anteriores a las del pintor francés. ${ }^{45}$ En el surrealismo estas imágenes adquieren connotaciones de auténtica liberación, al

42 J. L. EsTÉVEZ, «Masson en España», El País (Babelia), 26-V-2007, p. 26.

43 J. L. PlaZA CHILlón, «Degollaciones, decapitaciones, amputaciones... La poética de la violencia en los dibujos de Federico García Lorca», en: XVI Congreso Nacional de Historia del Arte: "La multiculturalidad en las artes y en la arquitectura", Las Palmas de Gran Canaria, 2006, pp. 831-841, T. I, y J. L. PlaZA CHILlóN, «Imágenes premonitorias de una guerra: Federico García Lorca y la poética de dolor. Una visión plástica», en: A. Colorado Castellary (ed.), Actas del Congreso Internacional, "Patrimonio, Guerra Civil y Posguerra", Madrid, 2010, pp. 461-473.

44 G. BAtaille, Las lágrimas de Eros, Barcelona, 1997, p. 213.

${ }^{45}$ P. Mayayo, André Masson: Mitologías. Madrid, 2002, pp. 101-153. menos en lo referido a la decapitación, si bien se introducen otros elementos iconográficos que a veces aparecen como contradictorios y que se unen paradójicamente, como fertilidad y esterilidad, sexualidad e impotencia, o nacimiento y muerte. ${ }^{46}$

El tema del sexo femenino se erige en el elemento central de estos dibujos lorquianos, especialmente evidenciado en la "Venus" del poema "Agua sexual" del libro de Neruda. En la vagina que se abre como un abanico de abundante y llamativas gotas de sangre, aparecen además las reiterativas "manos" que afloran del mismo, con el desmembramiento de pies y manos, sin olvidar la esperanza, que es simbolizada en los temblorosos flecos que salen de la boca y se transforma en la palabra "Amor", alargándose aún más en otro que termina con la tanática palabra "luna", en una constante alusión conceptual del "amor y la muerte" como principio y fin de todo, pero también como símbolo y elemento castrador. Aunque la visión de los genitales mutilados femeninos, destrozados y sangrantes, enlaza conceptualmente con la teoría, apuntada por Marful, del "coito sádico", al tiempo que apuntala esa amenaza de castración que es característica del complejo de Edipo. La mujer, por tanto, objetiviza la amenaza de la castración característica de este complejo, y por eso Lorca no ahorra en detalles cuando muestra o describe el horror que le produce la visión del sexo femenino. ${ }^{47}$ Ello explicaría también parte del guión cinematográfico Viaje a la luna, donde en el plano 5 apunta: "Letras que digan 'Socorro, socorro, socorro' con doble exposición sobre un sexo de mujer con movimiento de arriba

${ }^{46}$ E. DE DIEGO, «De la muerte, los demás y otras parábolas modernas», Revista de Occidente, 201,1998, pp. $47-60$.

${ }^{47}$ I. MARFUL, Lorca y sus dobles. Interpretación psicoanalítica de la obra dramática y dibujísitca, Kassel / Oviedo, 1991, pp. 114-115. 
abajo"; ${ }^{48}$ sucede igualmente en los dibujos, cuya formulación plástica del "aterrador" sexo femenino castrado y castrador se manifiesta en Venus con una visión frontal del mismo, abierto y de color rojo, o en el Martirio de Santa Rodegunda, donde se desangra, mientras un animal "fabuloso", a modo de criatura apocalíptica, huye por el lado izquierdo. El guión Viaje a la luna está lleno de referencias a la sexualidad femenina y puede entenderse en una visión global, como una frustrada búsqueda amorosa presidida por la luna, astro nocturno en calidad simbólica de muerte y feminidad; así la plasmación plástica de dicho guión se manifiesta en esta serie de dibujos: las $V e$ nus, el pez-luna, los martirios de santos...; y tanta simbología arquetípica y mitológica recogida en El Público, que funciona como clave intertextual para la interpretación del guión cinematográfico.

La temática del erotismo trágico subyace en ambos textos poéticos y en sus dibujos complementarios; funciona también la conjunción de una serie de elementos femeninos y masculinos en el referencial y decisivo plano 5 del Viaje a la luna, donde se expone el "sexo femenino con un movimiento de arriba hacia abajo", apuntando a un contenido erótico aunque entendido como enfrentamiento conflictivo de la sexualidad femenina. El guión desemboca en la tragedia contenida en el citado dibujo: la consumación erótica va siempre acompañada de la muerte y por lo tanto sólo en esta se cumple la satisfacción del deseo. ${ }^{49} \mathrm{El}$ objetivo final del viaje se desdobla en erotismo y muerte, en las dos vertientes de un único deseo cuya constante nos lleva a reflexionar por el sentido de la obra lorquiana, cuya apreciaciones plásticas llegan en

\footnotetext{
${ }^{48}$ O.C. T., II, p. 1139

49 G. Bataille, El erotismo, Barcelona, 1992, pp.
} 131-151. estos dibujos a las más altas cotas de expresión. ${ }^{50}$

Dichas Venus están relacionadas directamente con los dibujos La fecundación del niño azucena (1927) y Epitalamio (1928) donde también es representado el sexo femenino, si bien aquí aparece ornamentado por un singular vello púbico similar al fragmento de la barba que adornará el rostro de los dibujos dedicados a Walt Whitman, evidenciando su carácter fálico. El vello se ha asociado tradicionalmente con la potencia sexual y con la pasión; y es preciso minimizar la pasión sexual de la mujer para que el espectador crea tener el monopolio de la pasión, sin olvidar que a su vez se relaciona con la "vagina dentata" (voraz boca devoradora de los atributos masculinos) que se "oculta detrás del vello púbico". ${ }^{51}$ Esta inclusión que realiza el poeta granadino del sexo en un ámbito arquetípicamente femenino se convierte o, mejor dicho, recupera a través del sexo, símbolo de la "cueva primigenia" y dadora de fertilidad, la figura de la madre; recuperando una tradición ancestral y mítica que supone volver a los orígenes. ${ }^{52}$ Las representaciones más antiguas se remontan al siglo XIV, cuando aparecieron las llamadas "mujeres-vicios" en las que cada parte del cuerpo evocaba un pecado, y una boca sobre el vientre hacía alusión a la sexualidad femenina voraz, ocultando en su belleza engañosa una boca infernal, a causa de su lubricidad original. ${ }^{53}$ Iconográficamente en el mundo del arte contemporáneo no ha sido un tema muy común, ni lo suficientemente tratado, al

\footnotetext{
50 A. MONEGAL, «Entre el papel y la pantalla: Viaje a la luna de Federico García Lorca», en: J. GARCíA GALLEGO, (ed.). Surrealismo. El ojo..., pp., 242-258.

51 J. BERGER, Modos de ver, Barcelona, 1974, p. 64.

$52 \mathrm{M}$. ELIADE, El mito del eterno retorno: arquetipos y repetición, Barcelona, 1984, pp., 26-32 y 127-133.

${ }^{53}$ R. Muchembled, Historia del diablo. Siglos XIIXX, Madrid, 2004, p. 68.
} 
menos explícitamente; serán los surrealistas "amparados" por Freud los que indagarán en multitud de ocasiones, así artistas como Masson, Picasso o Dalí, se acercarán sin ningún tipo de tabú. Lorca se anticipa, de alguna manera, a esta línea poética tan imaginativa como transgresora.

La obra que ejemplifica mejor este modelo iconográfico del sexo femenino abierto como arquetipo mítico es si duda $E l$ origen del mundo del pintor realista francés Gustav Courbet (1866) que fue propiedad de Jacques Lacan; una obra que estuvo camuflada durante años con una versión pictórica menos directa, encargada por el psicoanalista parisino al pintor André Masson. Algún crítico al referirse a la obra de Courbet, ha señalado analogías entre ambas obras, especialmente al referirse a las "cuevas" que el pintor surrealista solía representar haciendo un paralelismo con la vagina femenina, respondiendo a la vez con la creación de un "panel-máscara" para tapar el original. ${ }^{54} \mathrm{El}$ propio título evoca connotaciones teológicas (dios, autor del mundo), mancillado y eclipsado por el imperio biológico materialista. Courbet traslada al espectador a un ámbito de intimidad, a un momento concreto en el que parece inevitable el contacto sexual, aunque en los dos casos, el sexo femenino implica un ojo (un objetivo) enteramente fálico. ${ }^{55}$ Tanto en la obra de Courbet como en la de Masson, el cuerpo de la modelo se convierte en un "paisaje" sexualizado, eliminando el rostro de la propietaria, con una parcelación selectiva del cuerpo poniendo enfáticamente de relieve un orificio fisiológico objeto de deseo sobre un fondo de resonancias telúricas, con el vello púbico florecido a modo de

\section{-}

\footnotetext{
${ }^{54}$ P. GEORGEL, Courbet: le poème de la nature, Paris,

${ }^{55}$ CATÁlogo-Exposición, Jardín de Eros, (A cargo de V. Combalía y J. J. Lebel). Madrid, 1999, y J. ABAD, (ed.). El origen del mundo. Antología, Madrid, 2004
} 1995. matorral y asomando los senos como dos montículos en la lejanía: todo parece coincidir con los dibujos de García Lorca, incluso la fragmentación del cuerpo de la mujer por los límites del lienzo ya que las piernas son cortadas y ni siquiera aparecen los brazos, y el hecho de que el elemento central del mismo sea el sexo femenino, se hace comparable a los dibujos Epitalamio y $\mathrm{La}$ fecundación del niño azucena. Es verdad que las obras referidas de Masson fueron realizadas después de los dibujos de Federico; sin embargo, la fascinación por el tema provenía de los primeros años de surrealismo, y precisamente esta visión de la imagen de la mujer recostada con las piernas abiertas dejando al descubierto la abertura de sexo se convierte nuevamente en arquetipo visual, al que responde no solo la obra de Masson, sino la de otros pintores surrealistas como Ernst, Dalí, Delvaux o Miró, sin olvidar la evocación hiperrealista y sacrificial de Étant donnes (1946-66) de Duchamp. ${ }^{56}$ Podemos vislumbar en el dibujo Teorema del jarro (1927) dentro de su matizada abstracción, elementos del cuerpo femenino delimitados por unas formas $y$ líneas que parecen sugerir un desnudo de mujer, con sexo y vello púbico de exaltada expresión amenazante, y comparar a las fragmentadas Venus en un juego plásticopoético, anticipando la premonición de la tragedia y el dramatismo de sus dibujos femeninos posteriores. Bien es verdad que en los estereotipos analizados hasta ahora, encontramos dos imágenes de mujer bien diferentes aunque no contrapuestas, ya que si por un lado existen damas con madroños, muchachas melancólicas y monjas llorando, y por otro, las Venus de hiriente y castradora sexualidad, en ambos casos se insinúa la asociación de lo femenino a la tragedia del

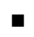

56 J. R. RAMírez, Corpus solus. Para un mapa del cuerpo en el arte contemporáneo, Madrid, 2003, pp. 293296. 
amor ligado a la muerte cuyo símbolo omnipresente siempre es la luna.

\section{CUERPOS GROTESCOS}

En el arte cristiano la imagen del martirio puede considerarse una especie de "objeto de transición" iconográfico, que también contiene la muerte. El martirio posee un carácter de transición derivado de la decisión consciente de aceptar la muerte para mantener vivo un sistema de creencias. Parte de este sistema de creencias es la convicción de que el mártir volverá a nacer en el cielo y alcanzará vida eterna. ${ }^{57} \mathrm{El}$ castigo físico, la vejación y la tortura son cosas muy antiguas con gran predicamento en la tradición cristiana. Las Actas de los mártires y las numerosas vidas piadosas escritas en los siglos posteriores están plagadas de descripciones espeluznantes relativas a las penalidades corporales sufridas por los primeros santos. ${ }^{58}$ Tanto el martirologio como el infierno, desde la alta edad media hasta finales de la edad moderna, están plagados de cuerpos heridos, masacrados, golpeados, quemados y mutilados, en un catálogo de vejaciones que satisface la exigencias de un sadismo verdaderamente enciclopédico. En esta tradición iconográfica del martirio cristiano existe una asombrosa escisión entre lo que se inscribe en el rostro y lo que sucede en el cuerpo, ya que las caras de los santos normalmente demuestran una fácil superioridad ante lo que sucede en la ruina del cuerpo. ${ }^{59}$ En el arte contemporáneo se mantendrá esta tradición aunque muy alejada de aquella religiosidad febril de antes; pintores como Otto Dix, José Caballero, Max Beckman, Masson o Dalí, se

${ }^{57}$ L. SCHNEIDER ADAMS, Psicoanálisis y arte, Madrid, 1996, p. 200.

${ }^{58}$ A .A. V. V. Actas de los mártires, Madrid, 1987.

${ }^{59}$ S. SONTAG, El SIDA y sus metáforas, Barcelona, 1989, pp. 45-46. harán partícipes de esta veta artística plagada de sadismo, donde hombres, pero sobre todo mujeres son torturadas dándole una ambigüedad sexual que otorga al género femenino en el arte de las vanguardias el papel de víctima de una actividad sádica y asesina; aunque buscando un acceso al éxtasis a través del sacrificio con un vínculo fundamental entre el éxtasis religioso y el erotismo. $^{60}$

La sexualidad hiriente, el martirio, el desmembramiento, el sacrificio, el cuerpo grotesco y la muerte femenina se aúnan en dos de los dibujos más interesantes del corpus lorquiano; las obras pertenecen a la serie neoyorquina y tratan un tema tradicional y áureo: el Martirio de Santa Rodegunda. El primer dibujo excepcionalmente fechado en Nueva York en 1929 y actualmente a la Fundación del poeta, es titulado por su creador como Muerte de Santa Rodegunda, y ayuda a datar el guión cinematográfico, Viaje a la luna, ya que aparece citado dicho "martirio" en el plano 36 del mismo cuando apunta: "Doble exposición de barrotes pasan sobre un dibujo: 'Muerte de Santa Rodegunda'";61 o Radegunda como es corregido por Marie Laffranque, que considera que se trata de una errata cometida por Lorca. ${ }^{62}$ Pero tal vez Federico se refería a otro dibujo que recrea la misma escena, aunque de composición mucho más compleja, ya que aparecen otras figuras y un animal "fabuloso" que repetirá en varios dibujos neoyorquinos; se trata de iMuerte

${ }^{60}$ G. BATAILLE, Las lágrimas de..., pp. 247-250.

61 O.C. T. II, p. 1143.

${ }^{62}$ F. GARCÍA LORCA, Viaje a la luna (guión cinematográfico), (Edición e introducción de M. Laffranque). Loubbressac, 1980. De la misma autora véase: «Equivocar el camino. Regards sur un scénario de Federico García Lorca», en: A. A. V .V. Hommage á Federico García Lorca, Toulousse-Le-Mirail, 1982, pp. 73-92. 
de Santa Rodegunda? (1929) conservado en la Pierpont Morgan Library de Nueva York. ${ }^{63}$

Sea un dibujo o el otro al que se refiere Lorca en su guión cinematográfico, da igual, ya que la similitud iconográfica es tal que sostenemos que el segundo dibujo es un versión más completa y desarrollada del primero, sobre todo, porque la figura central del mismo, Santa Rodegunda, coincide en ambos. De lo que no hay duda es que los dos completan junto al resto, el sentido poético de angustia, soledad, barbarie, erotismo sádico y muerte que transmite el poemario escrito en la ciudad de los rascacielos. Como ocurre en su "alter ego", Un perro andaluz, el guión de Lorca está repleto de escenas con contenido sádico que transmiten la impresión de una atmósfera amenazadora, opresiva e inquietante, se trata de una representación metafórica del deseo y de su frustración, desarrollando poética $\mathrm{y}$ violentamente el tema de la identidad sexual. Supondría, por tanto, este guión un viaje psíquico a la luna en calidad de símbolo de la muerte, en busca de un amor que se demuestra imposible. Es el viaje de Lorca hacia su propia aniquilación sexual, aunque con un itinerario bastante críptico y por buenas razones. ${ }^{64} \mathrm{El}$ guión lorquiano se muestra paralelo a estos dos dibujos, y a otros más del ciclo neoyorquino, además de coincidir estética y formalmente con los "poemas en prosa" que funcionan a modo de pantalla cinematográfica, y pueden presentarse como la proyección gráfica e icónica del irrealizado film. ${ }^{65}$ Como en las "degollaciones" de los "poemas en prosa", en

${ }^{63} \mathrm{M}$. HERNÁNDEZ, «Caleidoscopio de los dibujos lorquianos», en: CATÁLOGO-EXPOSICIÓN. Federico García Lorca. Dibujos, Caracas, Buenos Aires, México D.F., Nueva York, 1987, pp. 75-76.

${ }^{64}$ R. GUBERN, Proyector de luna. La generación del 27 y el cine, Barcelona, 1999, pp. 452-455.

65 K. POWER, «Una luna encontrada en Nueva York», Trece de nieve, 1-2, 2ª época, 1976, p. 143. las Venus de sexos heridos o en el Martirio de Santa Rodegunda, en Viaje a la luna el empleo del cuadro cinematográfico se vuelve violento y sexual: una orgía de sangre, vómitos y muerte. ${ }^{66}$

Lorca en la representación plástica de este martirio no sigue la tradición de la vida y la leyenda de la santa francesa del siglo $\mathrm{VI}^{67}$, creemos que el granadino en una interpretación muy libre del martirio acude para inspirarse a la Leyenda Dorada ${ }^{68}$ donde descubrimos que el artista "inventa" la muerte de la santa sobre una extraña mesa que se repite en los dos dibujos y que recuerda a la "Maldoriana" mesa de operaciones descrita por Lautrémont, en un hallazgo universal de definición de belleza surrealista "institucionalizada" por Breton. ${ }^{69}$ Llama especialmente la atención en el segundo dibujo la aparición del animal "fabuloso" que se repite en otros dibujos neoyorquinos, y que aquí podría suponer un símbolo evidencial de una probable "violación" a la mujer, lo que habría provocado la abundante hemorragia en el sexo de la misma y que prácticamente desborda el dibujo, además del abundante vello púbico que hace resaltar su herida feminidad.

Lo más llamativo en ambos dibujos es, sin duda, el deformado y "grotesco" cuerpo de la santa, estética que repite en bastantes dibujos, y que era algo bastante habitual entre los pintores del grupo surrealista la fijación por plasmar iconográfi-

${ }^{66}$ L. MARTínez Cuitiño, El mito del andrógino en Federico en Federico García Lorca, Buenos Aires, 2002, pp. 111-141.

${ }^{67}$ G. Duchet-Suchaux, M. Pastoreau, La Biblia y los santos. Guía iconográfica, Madrid, 1999, pp. 229-230.

68 S. DE LA VORÁGINE, La leyenda dorada, Madrid, 1982, p. 982, Vol. II.

${ }^{69}$ LAUTRÉAMONT (Isidore Ducasse, Conde de Lautréamont), Los cantos de Maldoror (ed. y traducción de M. Serrat), Madrid, 1988, pág., 125. 
camente un organismo sometido a la desfiguración, al suplicio y a la destrucción de una anatomía completamente desmaterializada. Conceptualmente el "cuerpo grotesco" puede acuñarse en la contemporaneidad al crítico ruso Mijail Bajtin, que analiza las características de la representación de esta forma de entender la desfiguración del cuerpo humano durante la edad media y el renacimiento y cuya tradición llega hasta el siglo XX en movimientos como el surrealismo, expresionismo o los "fauves". ${ }^{70} \mathrm{La}$ imagen grotesca del cuerpo ignora la superficie impenetrable e impoluta que da cobijo al organismo, y el realismo grotesco (en este caso surrealismo/ expresionismo grotesco) se manifiesta en el interior del mismo: la sangre, las entrañas, las venas, los vómitos, los excrementos; atribuyéndose un esencial papel a aquellos lugares en los que éste se desborda, rebasando sus propios límites (orificios como la boca o la vagina, prominencias como las heridas del pecho o la propia sangre). ${ }^{71}$ Por tanto, como apunta el crítico Bodei, el arte tiene el deber concreto de ocuparse y profundizar en todas las manifestaciones deformadas y desfiguradas, o sea de lo "feo" como símil de belleza perversa, y escapar así de los poderes establecidos. $^{72}$

Todo este mundo fisiológico y escatológico donde la visión del interior del cuerpo, la exhibición espectacular de la sangre y otros fluidos vitales, se convirtió en uno de los temas predilectos de Bataille y Documents; en dicha revista se publicó un influyente artículo cuya pretensión era explicar el mundo de los "sacrificios humanos

70 B. FERnÁNDEZ RUIZ, De Rabelais a Dalí. La imagen grotesca del cuerpo, Valencia, 2005, pp. 164-205.

${ }^{71}$ M. BAJTIN, La cultura popular en la Edad Media y el Renacimiento. El contexto de François Rabelais, Madrid, 1987, pp. 285-286.

72 R. BODEI, «La sombra de lo bello», Revista de occidente, 201,1998, pp. 14-16. de centro América", ${ }^{73}$ y cuyo texto estaba ilustrado con la imagen de un ritual azteca del "sacrificio de la extracción del corazón" perteneciente al Codex Vaticanus. ${ }^{74}$ Llama especialmente la atención la violencia visual y cromática que el artista logró traducir en el derramamiento de sangre de la figura principal, y que podríamos extrapolarlo poéticamente, sin establecer comparaciones, al lorquiano Martirio de Santa Rodegunda; sorprende, sobre todo, su similitud iconográfica. La imagen del manuscrito iluminado fascinó a Bataille, que la incluyó en alguna de sus publicaciones y sus estudios sobre los sacrificios humanos, y considera que "es generalmente un acto del sacrificio (martirio) el concordar la vida con la muerte" ${ }^{75}$ Por ello considera el crítico francés que el sentido último del erotismo es la muerte, (del sexo a la sangre hay poca distancia, apenas más distancia que de la sangre a la muerte $)^{76}$, y todo unido a los conceptos de sexualidad, represión y sublimación como ejemplos de la pérdida del placer erótico; que en Lorca es conducido hacia el camino del arte, ya sea poesía o drama, pero sobre todo en sus dibujos, convertidos en objetos de seducción para su particular lucha contra la castración. ${ }^{77}$

73 R. Hervé, «Sacrifes humanes de CentreAmérique», Documents, 4, 1930, pp. 205-213.

74 «Sacrificio humano. México. Iluminación del manuscrito: Codex Vaticanus», 37 38, fol. 54 №, Biblioteca Vaticana.

${ }^{75}$ G. BATAILle, El erotismo, Barcelona, 1997, p. 200.

${ }^{76} \mathrm{M}$. ONFRAY, «El sexo, la sangre y la muerte», $R e-$ vista de occidente, 201,1998, pp. 33-46.

77 N. O. BROWN, Eros y Tánatos. El sentido psicoanalítico de la historia, México, 1980, p. 82. 


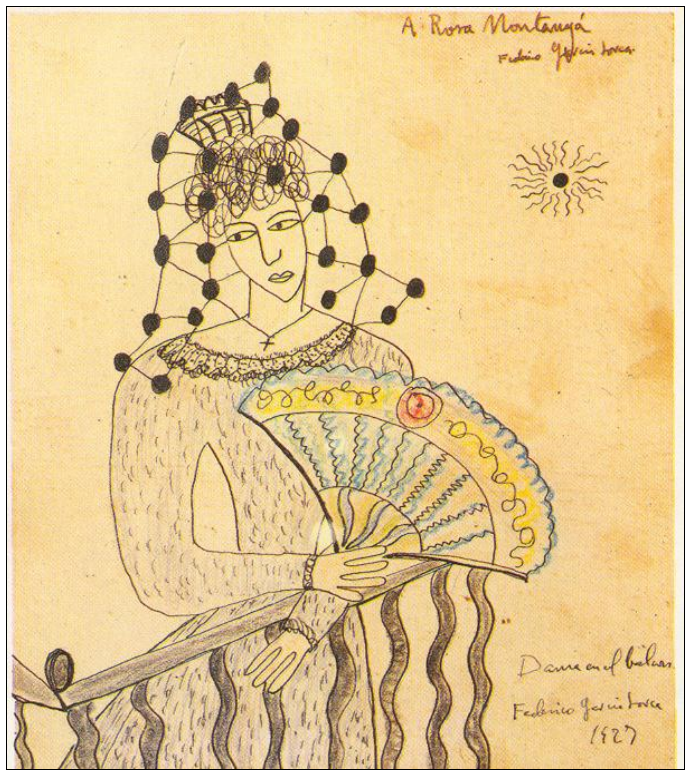

- Fig. 1. Federico García Lorca, Dama en el balcón, 1927.

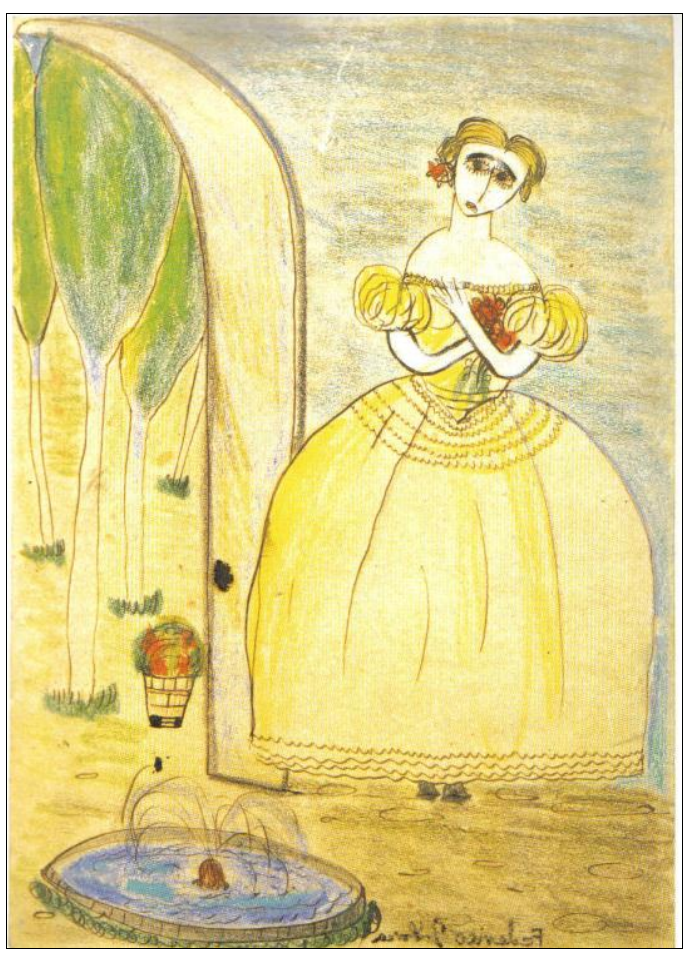

- Fig. 3. Federico García Lorca, Muchacha granadina en un jardín, 1924.

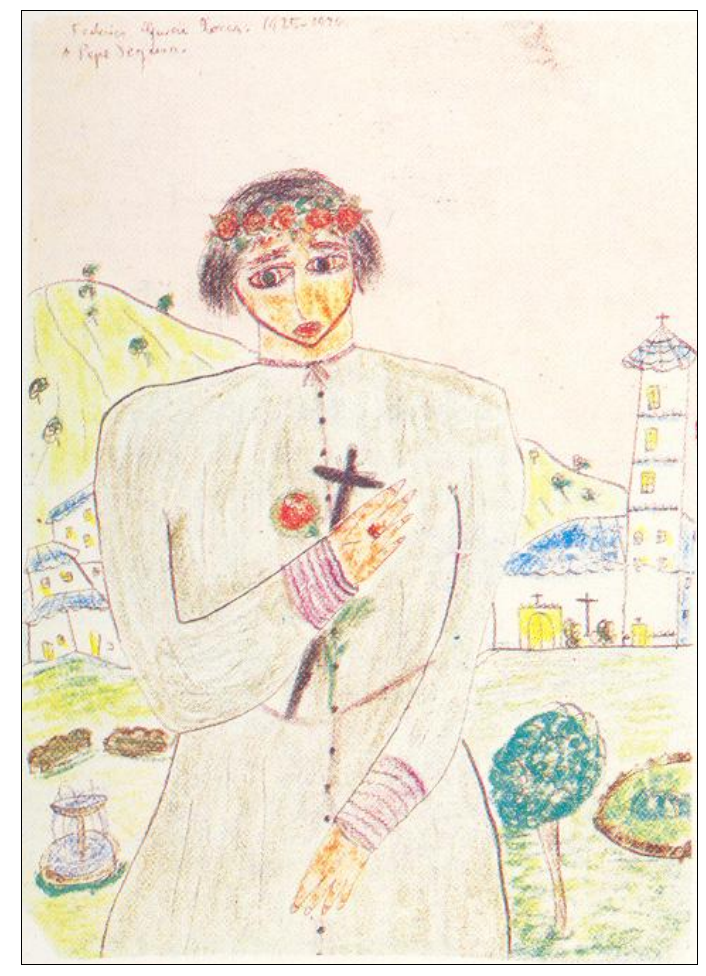

- Fig. 2. Federico García Lorca, Monja profesa con corona de flores, 1925. 


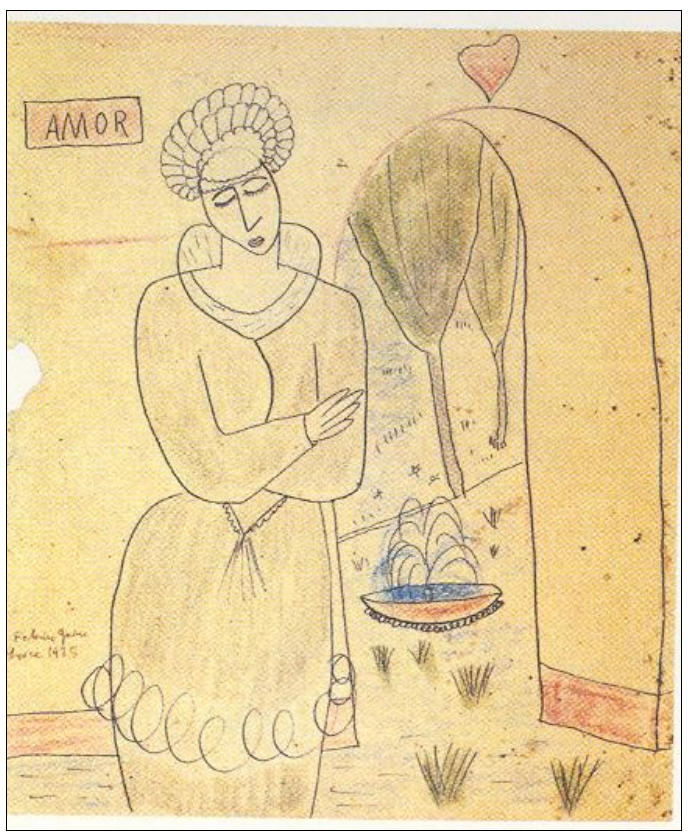

- Fig. 4. Federico García Lorca, Muchacha granadina en un jardín, 1925.

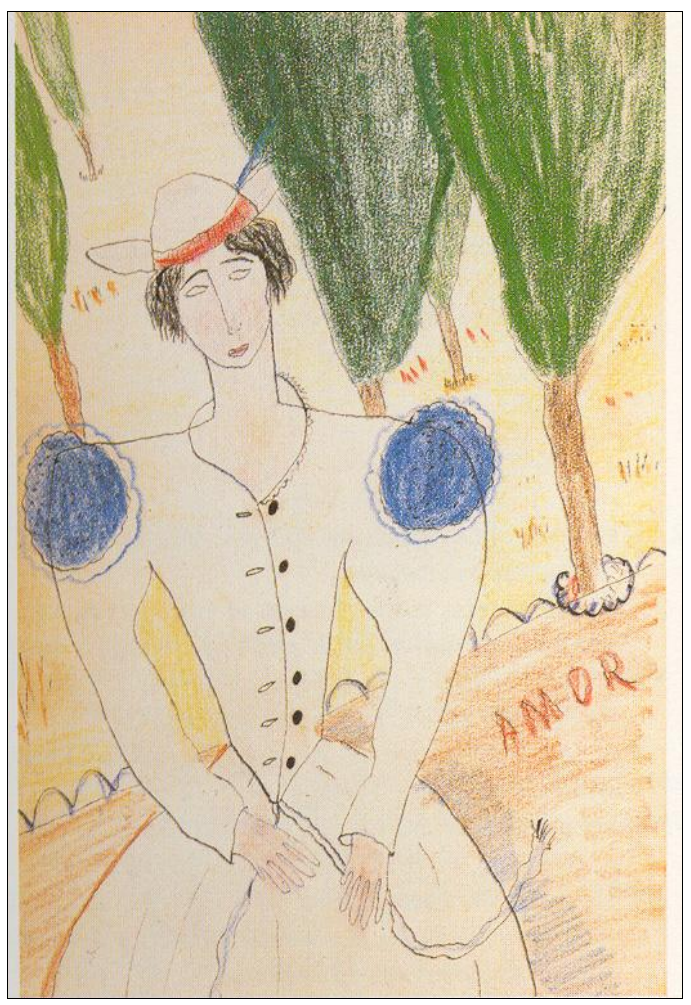

- Fig. 5. Federico García Lorca, Muchacha en un paseo de cipreses, 1930.

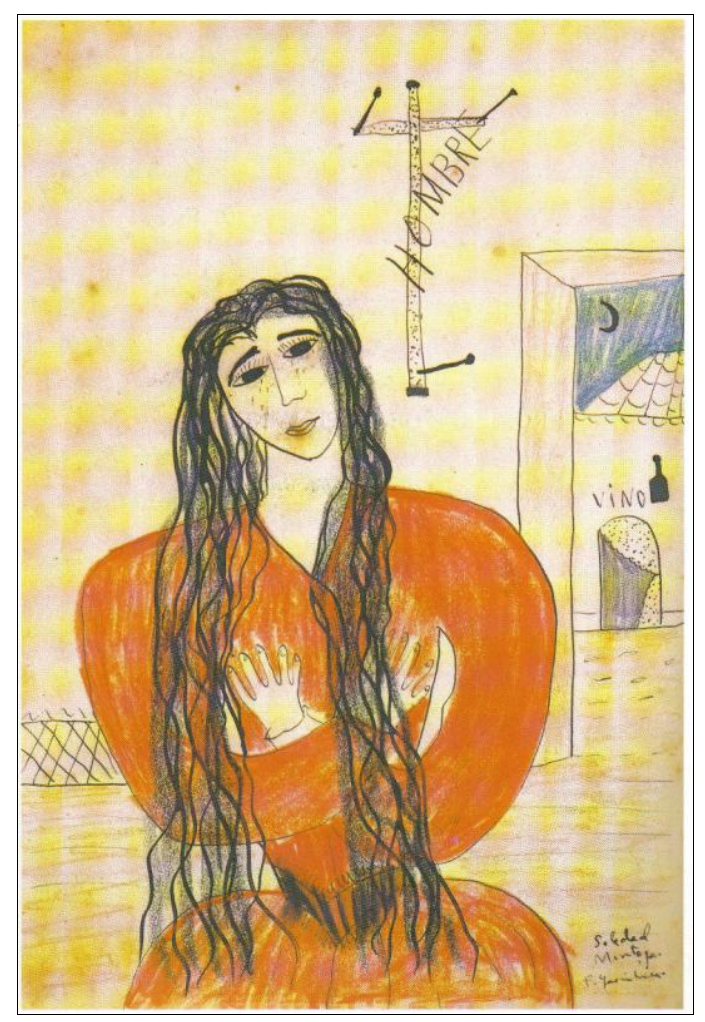

- Fig. 6. Federico García Lorca, Soledad Montoya, 1930. 


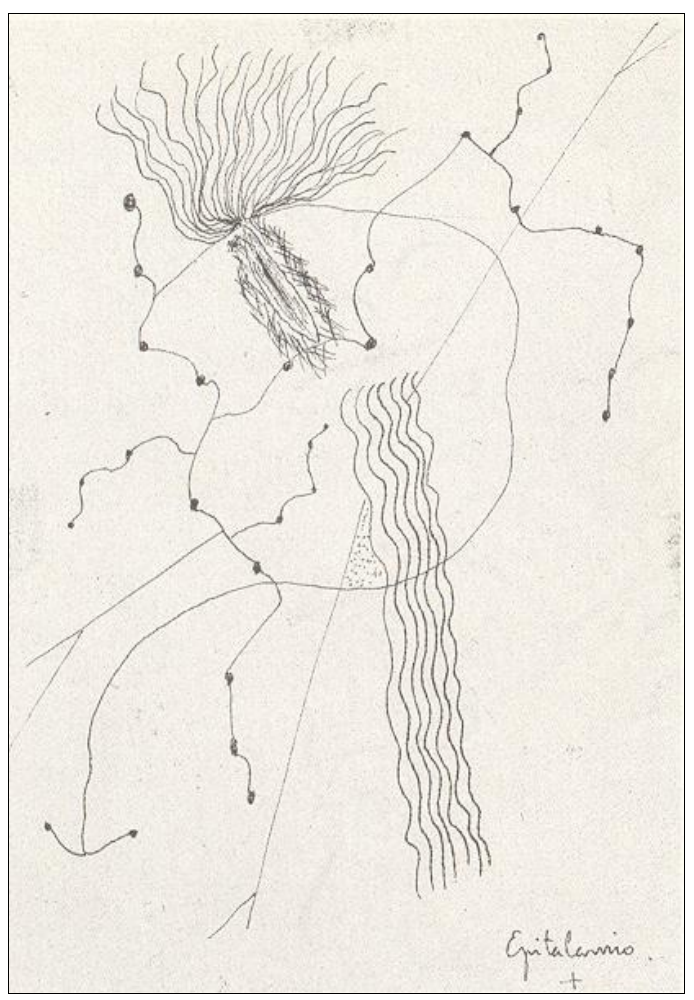

- $\quad$ Fig. 7. Federico García Lorca, Epitalamio, 1928.

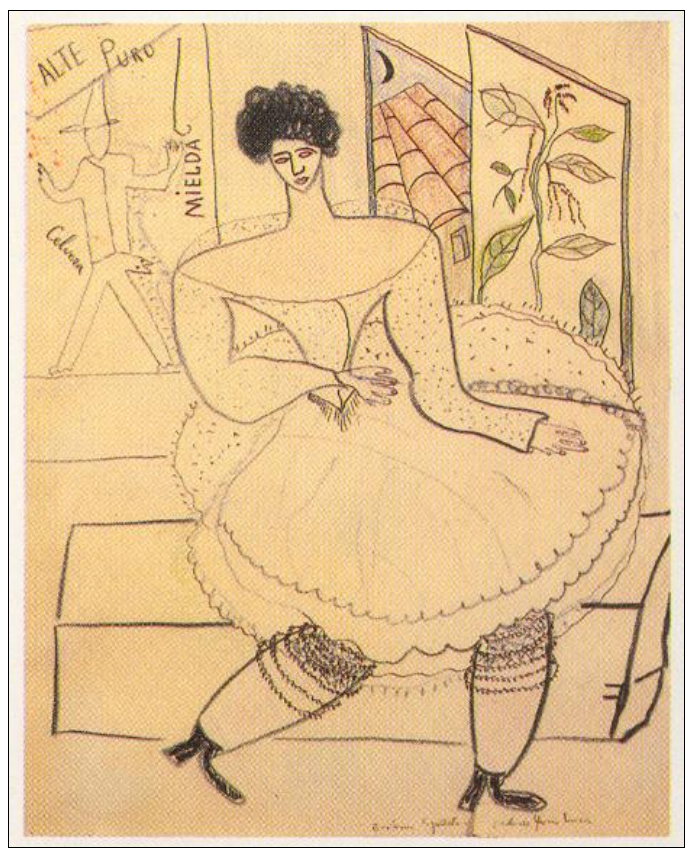

- Fig. 9. Federico García Lorca, Bailarina española, 1929-1932.

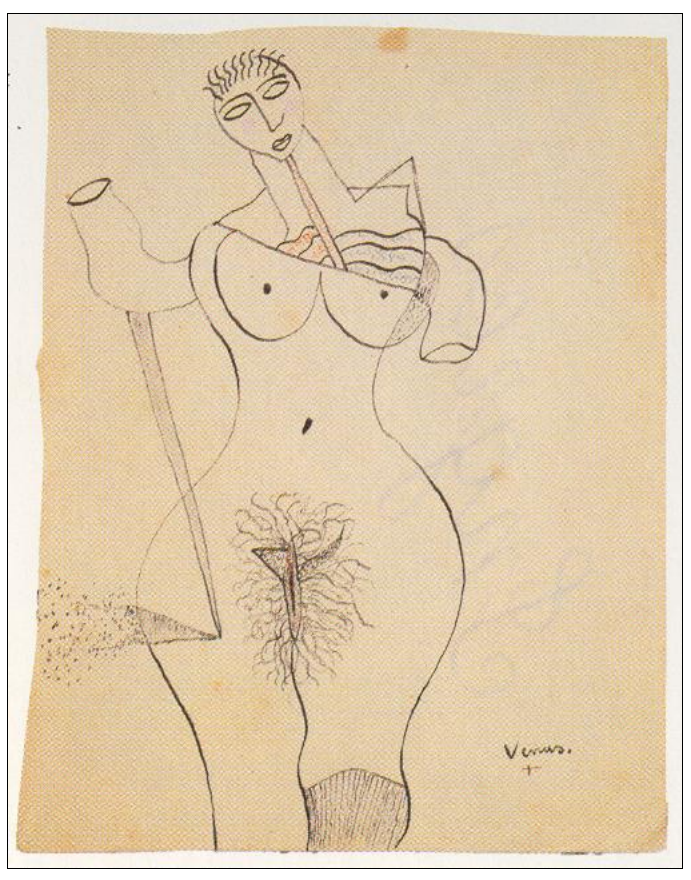

- Fig. 8. Federico García Lorca, Venus, 19271928.

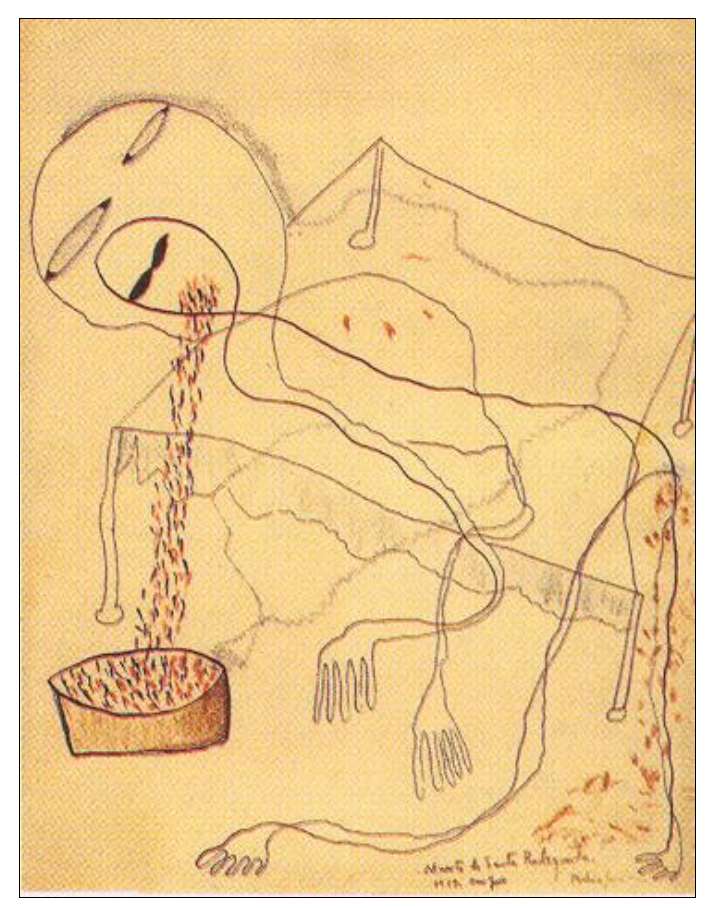

- Fig. 10. Federico García Lorca, Muerte de Santa Rodegunda, 1929. 


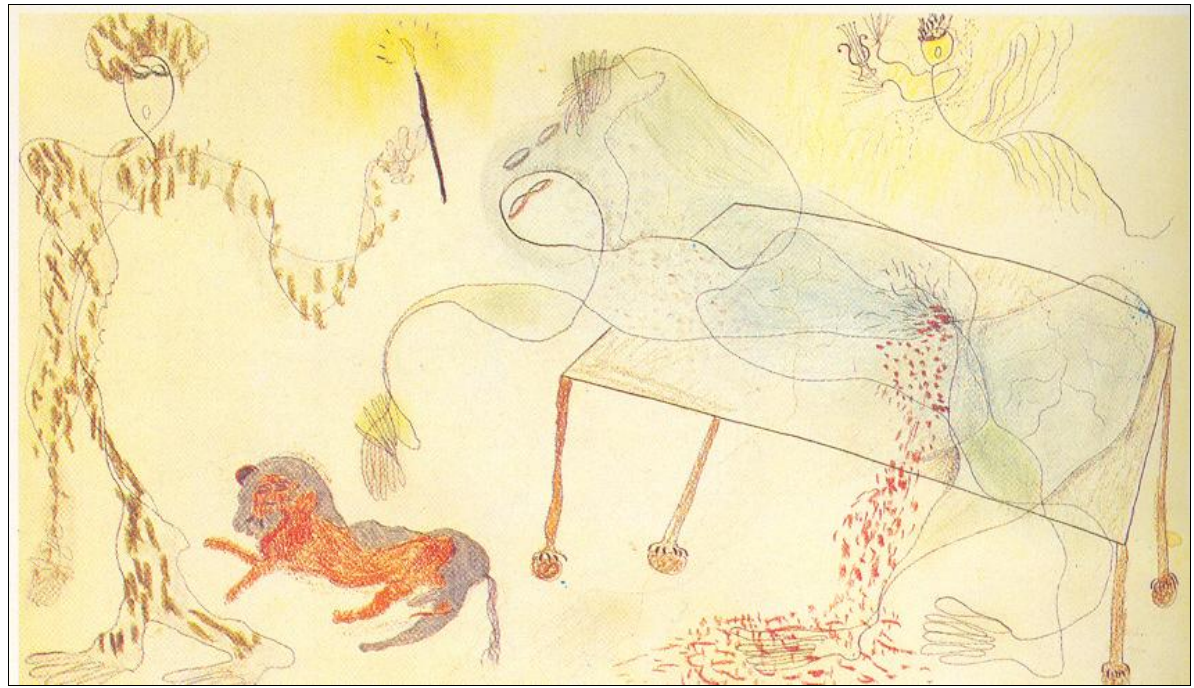

- Fig. 11. Federico García Lorca, ¿Muerte de Santa Rodegunda?, 1929.

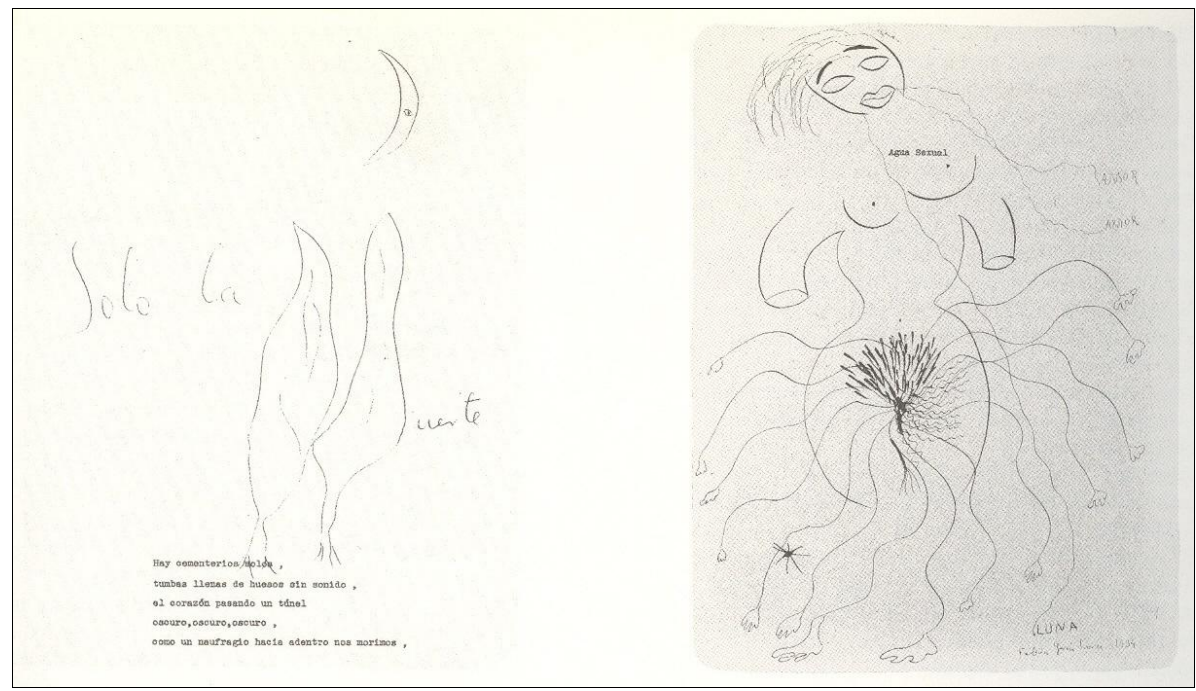

- Fig. 12. Federico García Lorca, Venus (Agua sexual), 1934.

Créditos: todas las imágenes han sido sacadas de: Mario HERNÁNDEZ, El libro de los dibujos de Federico García Lorca, Madrid, Tabapress / Fundación Federico García Lorca, 1990. 